\title{
The first two ganciclovir resistant cytomegalovirus isolates from kidney and pediatric stem cell transplant recipients in Turkey
}

\author{
Aysin Zeytinoglu ${ }^{1}$, Ajda Turhan ${ }^{2 *}$, Ahmet Keskinoglu ${ }^{3}$, Serap Aksoylar ${ }^{4}$, Nida Dincel ${ }^{3}$, \\ Burcu Deveci ${ }^{4}$, Ergul Utkun ${ }^{1}$, Sevgi Mir ${ }^{3}$ \\ ${ }^{1}$ Department of Medical Microbiology, Ege University Medical Faculty, Izmir, Turkey. \\ ${ }^{2}$ Blood Bank, Ege University Hospital, Izmir, Turkey. \\ ${ }^{3}$ Department of Pediatric Nephrology, Ege University Medical Faculty, Izmir, Turkey. \\ ${ }^{4}$ Department of Pediatric Hematology and Oncology Ege University Medical Faculty, Izmir, Turkey.
}

\begin{abstract}
Background: The emergence of cytomegalovirus (CMV) resistance to antivirals causes an increasing problem in transplant recipients, complicating therapeutic and clinical management. Widely used antivirals for therapy, preemptive therapy, and prophylaxis are the causes for resistance. This study aimed to report the first two transplant recipients who had CMV ganciclovir (GCV) resistance assessed by UL97 viral gene sequencing in Turkey.

Case presentation: CMV infection was monitored by plasma quantitative viral DNA real-time polymerase chain reaction (Abbott Molecular Inc., Illınois, USA) in the transplant recipients. Sequence analysis of CMV UL97 in CMV DNA-positive cases for GCV resistance was conducted, and while looking for UL97 GCV resistance in Ege University hospital, the first renal transplantation recipient with CMV mutation in Turkey was detected. Also, a stem cell transplant recipient was the first case for pediatric stem cell transplantation having UL97 GCV-resistant strain in Turkey. A594V and C603W mutations were the detected mutations, respectively.

Conclusion: Using GCV/valganciclovir (VGCV) for preemptive therapy, prophylaxis, treatment, and especially maintenance therapy for a long time with VGCV when CMV DNA is still detectable in peripheral blood might represent a risk factor for the emergence of CMV GCV resistance. The present findings indicate that resistance to widely used GCV as therapy, preemptive therapy, and prophylaxis should be monitored carefully in transplant recipients routinely for good patient management and effective antiviral therapy.
\end{abstract}

Key words: Cytomegalovirus, ganciclovir resistance, mutation, UL97

\section{Introduction}

$\boldsymbol{H}$ uman cytomegalovirus (CMV) is a serious complication for the immune-suppressed transplant recipients. Ganciclovir (GCV), used for treating CMV infection, is a deoxyguanosine analog and the first drug of choice in treating CMV infection in immunosuppressive patients. Recently, due to the widespread use of antiviral therapy, problems related to

CMV drug resistance are most likely to develop especially in transplant recipients (1-5). In solid organ transplant recipients, although drug resistance varies according to the organ transplanted and immunosuppressive treatment, it is usually between $5 \%$ and $10 \%$ in CMV seronegative recipients treated for $\mathrm{CMV}$ infection and higher in lung transplant recipients (4-8).

*Corresponding Author: Ajda Turhan. Ege University Hospital Blood Bank, Bornova, 35100, İzmir, Turkey. Tel: +90 2323904762 E-mail: ajdaturhan@gmail.com Received: May 31, 2016. Accepted: Jul 03, 2016 Published Online: Jul 12, 2016.

This is an Open Access article distributed under the terms of the Creative Commons Attribution Non-Commercial License (http://creativecommons.org/licenses/bync/4.0/) which permits unrestricted non-commercial use, distribution, and reproduction in any medium, provided the original work is properly cited. 
Because GCV is the first drug of choice in prophylaxis and preemptive therapy, UL97 resistance mutations are the most frequent mutations. With the development of resistance, antiviral therapy becomes completely ineffective, and it may produce results according to the condition of immunosuppression of the host, ranging from asymptomatic infection to the fatal disease.

In the case of clinical suspicion of drug resistance, it is recommended to confirm it with a laboratory test. The need for rapid diagnosis of drug resistance has led to the development of genotypic methods for determining the resistance mutations (9).

This study aimed to report the first two transplant recipients who had CMV GCV resistance assessed by UL97 viral gene sequencing in Turkey: a renal transplantation recipient and a pediatric stem cell recipient with CMV mutation.

\section{Material and methods}

Quantitative CMV DNA was detected with a Fluorion CMV QNP 3.0 Real-Time PCR Kit (iontek -Mag 16, iontek A.Ş, İstanbul) in samples in which nucleic acid isolation was performed. Then, the mutations defined for GCV (M460V, M460I, H520Q, A591V, C592G, A594V, A594T, L595S, E596G, K599T, C603V, C607F, and C607Y) were investigated with the help of UL97 sequence analysis. For the evaluation of UL97 gene region, ABI 3130 was used. The primers CMV_UL97_F GTTTCCACACAGACATGTTT and CMV_UL97_R GCATTCGTGGTAGAAGC were used in the analysis of a sequence of 700 base pairs. The genetic comparison was done with CMV AD169 strain.

\section{CASE 1}

A 17-year-old renal transplant recipient had a CMV infection posttransplant on day 35. Because he had a rise in serum creatinine levels, he received GCV $[10 \mathrm{mg} /(\mathrm{kg}$ day)] for 8 days, and valganciclovir (VGCV) (900 $\mathrm{mg}$ /day) was used afterward. During the follow-up when the patient was using VGCV, CMV DNA became positive $(11,790 \mathrm{IU} / \mathrm{mL})$ on day 175 . After receiving GCV therapy for 20 days, VGCV was started again using the same doses. Because CMV DNA was still positive $(2,138,500 \mathrm{IU} / \mathrm{mL})$ on day 193 , UL97 sequencing was done for GCV resistance and CMV UL97 A594V mutation was found. The same mutation was found in plasma samples collected on days 175 and 182 when analyzed retrospectively. In kidney biopsy specimens, microangiopathic and tubular changes were seen in the graft tissue. The basal values of creatinine were stable, and therefore immunsuppressive medication doses were decreased. The patient was followed up with CMV DNA measurements, and CMV DNA values decreased in time.

\section{CASE 2}

Stem cell transplantation was performed for Fanconi aplastic anemia in an 11-year-old girl. The recipient was seropositive, but the donor was seronegative before transplantation. The leukocyte engraftment date was 18 days, and the thrombocyte engraftment date was 31 days posttransplantation. Chimerism was $100 \%$. CMV DNA was found $(1587 \mathrm{IU} / \mathrm{mL})$ on posttransplantation day 10. Oral VGCV was started at a dose of $30 \mathrm{mg} /(\mathrm{kg}$ - day). One month posttransplantation, the patient suffered from graft versus host disease. In the second month, VGCV therapy was stopped when CMV DNA was found negative in two consecutive plasma samples. After 45 days, CMV DNA levels rose to $2086 \mathrm{IU} / \mathrm{mL}$, and GCV therapy was started at a dose of $10 \mathrm{mg} /(\mathrm{kg}$ - day). CMV DNA levels were always positive $(<1000 \mathrm{IU} / \mathrm{mL})$ till the 10th month posttransplantation even after maintenance therapy with VGCV. When levels rose to 2,197,584 $\mathrm{IU} / \mathrm{mL}$ in the 10th month posttransplantation, CMV C603W mutation was observed (posttransplantation day $319)$, and foscarnet $[180 \mathrm{mg} /(\mathrm{kg}$ - day)] for 2 weeks followed by $90 \mathrm{mg} /(\mathrm{kg}$ - day) with CMV HIG [(100 $\mathrm{mg} /(\mathrm{kg}$ - week)] was started. CMV DNA levels dropped to $2578 \mathrm{IU} / \mathrm{mL}$ in 2 weeks after therapy. Unfortunately the patient died because of bronchiolitis obliterans, pneumonia, and pulmonary bleeding on day 380 posttransplantation.

\section{Results and Discussion}

The clinical, therapeutic, and virological characteristics of these patients are listed in Table 1. The renal transplant patient had posttransplant CMV infection. He received GCV and VGCV therapy. Since CMV DNA levels were high during therapy, sequence analysis was done for GCV resistance and A594V mutation was found. The patient was the first renal transplant case with GCV resistance in Turkey. It was reported that A594V was the most frequent mutation $(10,11)$. Seropositive 
Table 1. Clinical, therapeutic, and virological characteristics of the patients.

\begin{tabular}{|c|c|c|c|c|c|c|c|c|c|}
\hline $\mathbf{P}$ & $\begin{array}{l}\text { Sex/Age } \\
\text { (year) }\end{array}$ & Tx & $\begin{array}{l}\text { CMV } \\
\text { D/R }\end{array}$ & $\begin{array}{l}\text { CMV inf } \\
\text { (days } \\
\text { PTx) }\end{array}$ & $\begin{array}{l}\text { Clinical } \\
\text { condition }\end{array}$ & Antiviral & $\begin{array}{l}\text { Dose } \\
{[(\mathrm{mg} /(\mathrm{kg}} \\
\text { day }]\end{array}$ & $\begin{array}{l}\text { GCV R } \\
\text { (days Ptx) }\end{array}$ & Outcome \\
\hline 1 & $\mathrm{M} / 17$ & Renal & $+/+$ & 35 & $\begin{array}{l}\text { Creatinine } \\
\text { levels } \uparrow \uparrow\end{array}$ & $\begin{array}{l}\mathrm{GCV} \rightarrow \\
\text { Oral VGCV }\end{array}$ & $\begin{array}{l}\text { GCV } 10 \\
\text { Oral } \\
\text { VGCV* }\end{array}$ & $\begin{array}{l}193 \\
\text { Mutation: } \\
\text { A594V }\end{array}$ & Alive \\
\hline 2 & $\mathrm{~F} / 11$ & $\begin{array}{l}\text { Stem } \\
\text { cell }\end{array}$ & $-1+$ & 10 & GVHD & $\begin{array}{l}\mathrm{GCV} \rightarrow \\
\text { Oral VGCV }\end{array}$ & $\begin{array}{l}\text { GCV } 10 \\
\text { Oral } \\
\text { VGCV* }\end{array}$ & $\begin{array}{l}319 \\
\text { Mutation: } \\
\text { C603W }\end{array}$ & Dead $^{* *}$ \\
\hline
\end{tabular}

D/R, donor/recipient; GCV, ganciclovir; GVHD, graft versus host disease; P, patient; PTx, posttransplant; Tx, transplant; VGCV, valganciclovir. *Adult: $900 \mathrm{mg} / \mathrm{kg}$ - day; pediatric: $30 \mathrm{mg} / \mathrm{kg}$ - day. **Because of bronchiolitis obliterans and pneumonia on day 380 posttransplantation.

recipients are at the risk of reactivation of a latent virus during immunosuppressive therapy, as well as of reinfection by a new virus strain hidden inside the allograft (12). Abundant data in the literature suggest that the resistance of CMV to GCV is associated with the lack of a therapeutic response and a progression to CMV disease (13). Some studies suggest that a high viral load, associated with the exposure to potentially inadequate levels of the drug, may increase the selection of drugresistant mutants (14).

The present study identified a pediatric transplant patient with CMV infection as the first pediatric stem cell transplant recipient with UL97 mutation identified in Turkey. Pediatric recipients are at high risk for CMV infection after transplantation following primary infection, reactivation of latent $\mathrm{CMV}$, or reinfection with a new strain (15). The incidence of GCV-resistant CMV infection has been reported to be $3.8 \%$ in pediatric allogeneic peripheral blood stem cell transplant recipients (16). The patient had Fanconi aplastic anemia, which might confer additional risk for persistent viremia leading to prolonged therapy and subsequent resistance.

One of the main risk factors for the emergence of resistance is D+/R- serostatus. However, resistance can also occur in seropositive organ recipients (17). Inadequate GCV doses can induce clinical resistance and favor the emergence of resistance-associated mutations within UL97 and, sometimes, UL54 (18).

Moreover, optimal ganciclovir doses can overcome virological resistance due to isolated UL97 resistance mutations, at least for a certain period (14).

The sequencing results of both cases are seen in figure 1 .

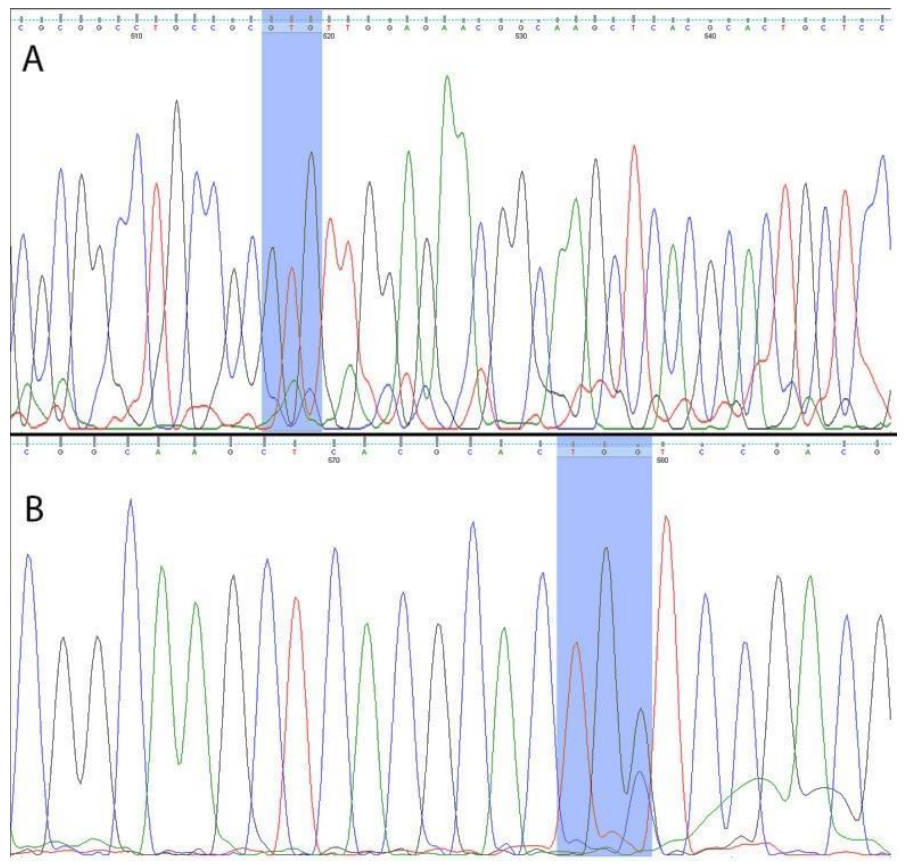

Figure 1: Sequencing results indicating mutations. In A, case 1 , the light blue area is showing the $\mathrm{A} 594 \mathrm{~V}$ mutation, a C > T substitution of the nucleotide that resulted in Ala594Val. In B, case 2, the light blue area is showing the $\mathrm{C} 603 \mathrm{~W}$ mutation, a $\mathrm{C}$ $>\mathrm{G}$ substitution of the nucleotide that resulted in Cys603Trp.

\section{Conclusions}

Using GCV/VGCV for preemptive therapy, prophylaxis, treatment, and especially maintenance therapy for a long time with VGCV when CMV DNA is still detectable in peripheral blood might represent a risk factor for the emergence of CMV GCV resistance.

The present findings indicated that resistance to widely used GCV as therapy, preemptive therapy, and prophylaxis should be monitored carefully in transplant recipients routinely for good patient management and effective antiviral therapy. 
Contributions: The authors contributed equally.

Ethics Committee Approval: Ethics Committee approval was received for this study from the ethics committee.

Informed Consent: Written informed consent was obtained from patients who participated in this study.

Peer-review: Externally peer-reviewed.

Conflict of Interest: No conflict of interest was declared by the author.

Financial Disclosure: The author declared that this study has received no financial support.

\section{References}

1. Humar A, Snydman D. Cytomegalovirus in solid organ transplant recipients. Am J Transplant 2009; 9: 78-86.

2. Limaye AP, Corey L, Koelle DM, Davis CL, Boeckh M. Emergence of ganciclovir-resistant cytomegalovirus disease among recipients of solid-organ transplants. Lancet 2000; 356: 645-649.

3. Lurain NS, Bhorade SM, Pursell KJ, Avery RK, Yeldandi $\mathrm{VV}$, Isada CM, et al. Analysis and characterization of antiviral drug-resistant cytomegalovirus isolates from solid organ transplant recipients. J Infect Dis 2002; 186:760-768.

4. Marfori JE, Exner MM, Marousek GI, Chou S, Drew WL. Development of new cytomegalovirus UL97 and DNA polymerase mutations conferring drug resistance after valganciclovir therapy in allogeneic stem cell recipients. $J$ Clin Virol 2007; 38: 120-125.

5. Torres-Madriz G, Boucher HW. Immunocompromised hosts: perspectives in the treatment and prophylaxis of cytomegalovirus disease in solid-organ transplant recipients. Clin Infect Dis 2008; 47: 702-711.

6. Limaye AP, Raghu G, Koelle DM, Ferrenberg J, Huang ML, Boeckh M. High incidence of ganciclovir-resistant cytomegalovirus infection among lung transplant recipients receiving preemptive therapy. J Infect Dis 2002; 185: 20-27.

7. Lurain NS, Chou S. Antiviral drug resistance of human cytomegalovirus. Clin Microbiol Rev 2010; 23: 689-712.

8. Eckle T, Lang P, Prix L, Jahn G, Klingebiel T, Handgretinger R, et al. Rapid development of ganciclovirresistant cytomegalovirus infection in children after allogeneic stem cell transplantation in the early phase of immune cell recovery. Bone Marrow Transplant 2002; 30: 433-439.

9. Wolf DG, Yaniv I, Honigman A, Kassis I, Schonfeld T, Ashkenazi S. Early emergence of ganciclovir-resistant human cytomegalovirus strains in children with primary combined immunodeficiency. J Infect Dis 1998; 178: 535-538.

10. Castor J, Cook L, Corey L, Jerome KR. Rapid detection directly from patient serum samples of human cytomegalovirus UL97 mutations conferring ganciclovir resistance. J Clin Microbiol 2007; 45: 2681-2683.

11. Chou S, Waldemer RH, Senters AE, Michels KS, Kemble GW, Miner RC, Drew WL. Cytomegalovirus UL97 phosphotransferase mutations that affect susceptibility to ganciclovir. J Infect Dis 2002; 185: 162-169.

12. Opelz G, Dohler B, Ruhenstroth A. Cytomegalovirus prophylaxis and graft outcome in solid organ transplantation: a collaborative transplant study report. Am J Transplant 2004; 4: 928-936.

13. Erice A. Resistance of human cytomegalovirus to antiviral drugs. Clin Microbiol Rev 1999; 12: 286-297.

14. Emery VC, Griffiths PD. Prediction of cytomegalovirus load and resistance patterns after antiviral chemotherapy. Proc Natl Acad Sci USA 2000; 97: 8039-8044.

15. Bueno J, Ramil C, Green M. Current management strategies for the prevention and treatment of cytomegalovirus infection in pediatric transplant recipients. Paediatr Drugs 2002; 4: 279-290.

16. Eckle T, Prix L, Jahn G, Klingebiel T, Handgretinger R, Selle B, Hamprecht K. Drug-resistant human cytomegalovirus infection in children after allogeneic stem cell transplantation may have different clinical outcomes. Blood 2000; 96: 32863289.

17. Hantz S, Garnier-Geoffroy F, Mazeron MC, Garrigue I, Merville P, Mengelle C, et al. Drug-resistant cytomegalovirus in transplant recipients: a French cohort study. J Antimicrob Chemother 2010; 65: 2628-2640.

18. Boutolleau D, Deback C, Bressollette-Bodin C, Varnous S, Dhedin N, Barrou B, et al. Resistance pattern of cytomegalovirus (CMV) after oral valganciclovir therapy in transplant recipients at high-risk for CMV infection. Antiviral Res 2009; 81: 174-179.

How to cite?

Distribution of the patterns in patients with positive antinuclear antibody and anti-extractable nuclear antigen. Yanik K, Unal N, Birinci A, Gunaydin M. J Immunol Clin Microbiol 2016; 1(3).

DOI: http://dx.doi.org/10.5455/jicm.11.20160629

Submit your next manuscript to the JICM and take full advantage of:

- Convenient online submission,

- Thorough peer review, Fast Response,

- No charges,

- Immediate publication on acceptance,

- Inclusion in Scopemed and High quality indexes,

- Research which is freely available for redistribution of the worldwide literature

To submit your manuscript, click on http://www.jiacm.com

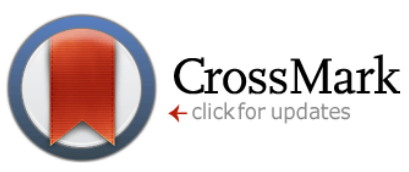

Published by The QMEL.org

International Medical Education Library

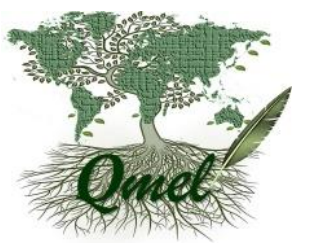

